\title{
Integrated Nutrient Management in Summer Cowpea (Vigna unguiculata L.) Under South Gujarat Condition
}

\author{
K.L. Pargi ${ }^{1}$, R.L. Leva ${ }^{2}$, H.Y. Vaghasiya ${ }^{3 *}$ and H.A. Patel ${ }^{1}$ \\ ${ }^{1}$ Department of Agronomy, N. M. College of Agriculture, Navsari Agricultural University \\ (NAU), Navsari, Gujarat, India \\ ${ }^{2}$ Division of Plant Biotechnology, ${ }^{3}$ Division of Microbial and Environmental Biotechnology, \\ Aspee Shakilam Biotechnology Institute, NAU, Surat, Gujarat, India \\ *Corresponding author
}

\section{A B S T R A C T}

\section{Keywords}

Cowpea, RDF, Rhizobium, Phosphate solubilizing bacteria, FYM

Article Info

Accepted:

10 August 2018

Available Online:

10 September 2018
A field experiment entitled "Integrated nutrient management in summer cowpea (Vigna unguiculata L.) under South Gujarat condition" conducted at Navsari with eight treatment combinations replicated thrice in factorial randomized block design during the summer season of 2016. The treatment consisted combinations of two levels of inorganic fertilizers $\left(\mathrm{F}_{1}: 50 \% \mathrm{RDF}, \mathrm{F}_{2}: 100 \% \mathrm{RDF}\right)$; two levels organic manures $\left(\mathrm{O}_{1}\right.$ : FYM @ $0 \mathrm{t} \mathrm{ha}{ }^{-1}, \mathrm{O}_{2}$ : FYM@ $\left.2.5 \mathrm{t} \mathrm{ha}^{-1}\right)$ and two levels bio-fertilizers $\left(\mathrm{B}_{1}\right.$ : No inoculation, $\mathrm{B}_{2}$ : seed inoculation with Rhizobium and phosphate solubilizing bacteria). As regards the growth parameters the higher plant height $(\mathrm{cm})$, number of branches per plant, days to $50 \%$ flowering, number of nodules per plant, dry matter per plant $(\mathrm{g})$, number of pod per plant, number of seed per pod, 100 seed weight $(\mathrm{g})$, higher grain $\left(\mathrm{kg} \mathrm{ha}^{-1}\right)$, haulm yield $\left(\mathrm{kg} \mathrm{ha}^{-1}\right)$, harvest index (\%) were significantly increased to a greater extent by the treatment $100 \% \mathrm{RDF}$ $\left(\mathrm{F}_{2}\right)$, FYM @ $2.5 \mathrm{t} \mathrm{ha}^{-1}\left(\mathrm{O}_{2}\right)$ and seed inoculation with Rhizobium and phosphate solubilizing bacteria $\left(\mathrm{B}_{2}\right)$ which was found significantly differ from the $50 \% \mathrm{RDF}\left(\mathrm{F}_{1}\right)$, FYM @ $0 \mathrm{t} \mathrm{ha}^{-1}\left(\mathrm{O}_{1}\right)$ and No inoculation $\left(\mathrm{B}_{1}\right)$ treatments.

\section{Introduction}

Cowpea (Vigna unguiculata L.) is a multipurpose kharif and warm season pulses crop, commonly cultivated all over India. It is also called as black eye pea, black eye bean, southern pea, china pea, marble pea, chowli and lobiya. West Africa and India are the centers of diversified for cowpeas. Cowpea is cultivated as seed, green vegetable and fodder in many diverse agriculture systems in many countries of Africa, Latin America, and south East Asia and in the southern United States (Singh et al., 2012). The largest cowpea seed producing nation are Africa, Nigeria, India, Brazil, Haiti, Myanmar, Sri Lanka, Bosnia, Australia and other West African countries. Cowpea is also called vegetable meat due to high amount of protein having better biological value. The mature cowpea seed 
contains 24.8 per cent protein, 63.6 per cent carbohydrate, 1.9 per cent fat, 6.3 per cent fiber, 0.00074 per cent thiamine, 0.00042 per cent riboflavin and 0.00281 per cent niacin as well as rich source of calcium and iron (Shaw M, 2007). Besides human consumption, cowpea may be suitably grown as forage, green manuring, cover crop and catch crop. It is also one of the alternatives in dry land farming systems as a mixed intercrop due to its fast growing habit and being legume. In India, cowpea is cultivated mainly in Rajasthan, Maharashtra, Karnataka, Gujarat, Tamil Nadu, Andhra Pradesh and Madhya Pradesh. In India, area under cowpea is 654 lakh hectares with a production of 599 lakh tonnes with productivity of $916 \mathrm{~kg} \mathrm{ha}^{-1}$ (Josji et al., 2018).

Cultivation of cowpea in summer season is increasing in Gujarat, especially in south Gujarat where perennial water supply from Ukai- Kakrapara project is available to meet the demand of irrigation. There is uncontrolled and discriminate use of chemical fertilizer has deteriorated the soil health, leading to drastic decline in crop productivity. Therefore, there is a need to use organic fertilizer like FYM and bio-fertilizers. Integrated or balance use of chemical and organic fertilizer not only increase the crop yield, but also improves the soil health. Role of these manures are undisputed but their unavailability and bulky nature limit their use. Gaur et al., (1990) reported that organic $\mathrm{N}$ is slowly mineralized and about $30 \% \mathrm{~N}, 70 \% \mathrm{P}_{2} \mathrm{O}_{5} 75 \% \mathrm{~K}_{2} \mathrm{O}$ is likely become available to the first crop and the rest of the nutrients to succeeding crops. Judicious use of chemical fertilizer: organic manures in $1: 1$ or $7: 3$ ratios maintain sustainable soil quality (Shankaram A, 1996).

The efficient application of chemical fertilizers have played very significant role in providing nutrients for growth and development of plants. Among different nutrients, nitrogen is one of the most expensive and important nutrient. Cowpea utilizes atmospheric nitrogen through symbiotic fixation to meet a major part of nitrogen requirement of crops. However, it requires a starter dose of nitrogen to boost up early growth and establishment. A sizeable amount of applied nitrogen could be lost as ammonia by volatilization from soil surface; nitrous oxide or elemental nitrogen by denitrification and nitrates by leaching in ground water. Indian soils are rich in phosphorus but more than two-thirds of the native phosphates are unavailable and applied phosphatic fertilizers rendered unavailable within a short period due to its chemical fixation in the soil as it is immobile in the soil.

Bio-fertilizers are formulations of beneficial microorganisms, which upon application can increase the availability of nutrients by their biological activity and help to improve the soil health for increasing soil fertility. Among different bio-fertilizers Rhizobium inoculation can increase the grain yield of pulse crops to the tune of 10 to 15 per cent.

Phosphate solubilizing bacteria (PSB) have the consistent capacity to increase the availability of phosphates to plants by mineralizing phosphorus compounds. Both the demand for larger amount of fertilizers and associated drain on foreign exchange and the associated environmental problems have forced us to think of alternate sources of plant nutrients. These needs have led to the development of the concept of INM. The concept of INM is the rationalization of plant nutrient management in order to upgrade the efficiency of plant nutrient supply to the crops resulting ultimately in higher productivity and income to the farmers including better impact on environment. It would be very necessary for a crop like cowpea to study various techniques in detail in order to improve its productivity and quality. 


\section{Materials and Methods}

The experiment was taken up on plot E - 23 of the College Farm, N. M. College of Agriculture, Navsari Agricultural University, Navsari during summer season of 2016. The experimental field was fairly leveled and uniform in fertility. The soil popularly known as "Deep Black" soils was an old alluvium of basaltic material by its origin. According to the seventh approximation, the soil of the experimental field is classified under the group Ustochrepts, sub group of Vertic ustochrepts, sub order orchrepts and order inceptisols with Jalalpur series. Soils are deep, moderately drained having good water holding capacity.

The soil crack heavily on drying and expands on wetting. The predominant clay mineral is montmorillonite. The soils having a $7.8 \mathrm{pH}$, low in organic carbon content $(0.53 \%)$, medium in available $\mathrm{N}\left(197.26 \mathrm{~kg} \mathrm{ha}^{-1}\right), \mathrm{P}$ $\left(30.93 \mathrm{~kg} \mathrm{ha}^{-1}\right.$ ) and higher in available $\mathrm{K}$ $\left(369.80 \mathrm{~kg} \mathrm{ha}^{-1}\right)$. The experiment comprising eight treatment combinations were laid out in factorial randomized block design with tree replication. The treatment consisted combinations of two levels of inorganic fertilizers $\left(\mathrm{F}_{1}: 50 \% \mathrm{RDF}, \mathrm{F}_{2}: 100 \% \mathrm{RDF}\right)$; two levels organic manures $\left(\mathrm{O}_{1}\right.$ : FYM @ $0 \mathrm{t}$ $\mathrm{ha}^{-1}, \mathrm{O}_{2}$ : FYM @ $2.5 \mathrm{t} \mathrm{ha}^{-1}$ ) and two levels bio-fertilizers (B1: No inoculation, $\mathrm{B}_{2}$ : seed inoculation with Rhizobium and phosphate solubilizing bacteria). In each plot five plants were selected at random and tagged for observations.

Observations on yield and its attributing characters viz., plant height $(\mathrm{cm})$, number of branches per plant, days to $50 \%$ flowering, number of nodules per plant, dry matter per plant $(\mathrm{g})$, number of pod per plant, number of seed per pod, 100 seed weight (g), grain yield $\left(\mathrm{kg} \mathrm{ha}^{-1}\right)$, haulm yield $\left(\mathrm{kg} \mathrm{ha}^{-1}\right)$, harvest index (\%) were recorded.

\section{Results and Discussion}

\section{Growth and yield parameters}

\section{Effect of inorganic fertilizer}

Data presented in Table 1 revealed that difference in plant height at 20 DAS, at 40 DAS, at 60 DAS and at harvest were influenced significantly by the effect of inorganic fertilizers. Plant height at initial stage of crop growth i.e. at 20 day after sowing (DAS) was found non-significant. Significantly the highest plant height at 40 DAS i.e. $31.77 \mathrm{~cm}$, at 60 DAS i.e. $42.73 \mathrm{~cm}$ and at harvest i.e. $45.39 \mathrm{~cm}$ was recorded with $100 \% \operatorname{RDF}\left(\mathrm{F}_{2}\right)$. Thus there is an increase in plant height with application of $100 \%$ RDF throughout the crop growth span. The probable reason might be positive effect of nutrient on growth character due to augment of cell division and cell expansion. The study was in close conformity as observed by Abayomi et al., (2008), Dekhane et al., (2011), Khandelwal et al., (2013), Khan et al., (2015) and Josji et al., (2018)

Number of branches per plant at harvest was also increased with an increase in $100 \% \mathrm{RDF}$ $\left(F_{2}\right) \quad($ Table 1) Nitrogen enhances the development of strong cell walls and therefore stiffer branches which might be resulted into profuse branches of cowpea. These results are already in agreement with those reported by Abayomi et al., (2008), Dekhane et al., (2011), Khandelwal et al., (2013), and Khan et al., (2015).

Most of the growth character and yield attributes viz., days to $50 \%$ flowering, number of nodules per plant, dry matter per plant, number of pod per plant, number of seed per pod and 100 seed weight were significantly higher with treatment $\mathrm{F}_{2}$ (100 \% RDF). Adequate major nutrients might have helped in harvesting of solar energy as reflected by 
increased dry matter accumulation. The beneficial effect of inorganic fertilizer in growth and yield attributes were also reported by Qureshi et al., (2015), Sarawd et al., (2014), Satodiya et al., (2015), Sharma et al., (2015) and Josji et al., (2018).

Similarly, seed and haulm yields (Table 3) of cowpea were also recorded significantly higher with application of $100 \% \operatorname{RDF}\left(\mathrm{F}_{2}\right)$ than other treatment. Application of $100 \%$ RDF gave significantly higher seed i.e. 917.58 $\mathrm{kg} \mathrm{ha}^{-1}$ and haulm i.e. $2221.33 \mathrm{~kg} \mathrm{ha}^{-1}$ yield. The highest seed and haulm yield could be due to the cumulative effect of improvement in yield attributes viz., number of pod per plant, number of seed per pod and 100 seed weight. The improvement in seed yield, haulm yield and harvest index were mainly on account of increase in the growth parameters and yield attributes of cowpea which resulted in higher production of photosynthates were utilized by the plant for development of sink under adequate supply of nutrients due to increasing in rate of inorganic fertilizer. These results are also in agreement with findings of Khandelwal et al., (2013), Sarawd et al., (2014), Khan et al., (2015), Qureshi et al., (2015), Satodiya et al., (2015), Sharma et al., (2015) and Joshi et al., (2018)

\section{Effect of organic manures}

Data furnished in Table 1 indicated that difference in plant height at $40 \mathrm{DAS}$, at 60 DAS and at harvest were influenced significantly by the effect of organic manures. Significantly the highest plant height at 40 DAS i.e. $31.87 \mathrm{~cm}$, at 60 DAS i.e. $42.91 \mathrm{~cm}$ and at harvest i.e. $45.46 \mathrm{~cm}$ was recorded with FYM @ $2.5 \mathrm{t} \mathrm{ha}^{-1}\left(\mathrm{O}_{2}\right)$. Thus there is an increase in plant height with application of FYM @ $2.5 \mathrm{t} \mathrm{ha}^{-1}$ throughout the crop growth span. The probable reason might be positive effect of nutrient on growth character due to augment of cell division and cell expansion.
The study was in close conformity as observed by Sankar et al., (1999), and Qureshi et al., (2015).

Number of branches per plant at harvest was also increased with an increase in FYM @ 2.5 $t h^{-1}\left(\mathrm{O}_{2}\right)$ (Table 1). Nitrogen enhances the development of strong cell walls and therefore stiffer branches which might be resulted into profuse branches of cowpea. These results are already in agreement with those reported by Sarkar et al., (1997), Sankar et al., (1999), Subbarayappa et al., (2009), and Qureshi et al., (2015).

Most of the growth character and yield attributes viz., days to 50\% flowering, number of nodules per plant, dry matter per plant, number of pod per plant, number of seed per pod and 100 seed weight were significantly higher with treatment $\mathrm{O}_{2}\left(\mathrm{FYM} @ 2.5 \mathrm{tha}^{-1}\right.$ ).

It might be attributed to better availability of nutrients at critical growth stages which facilitated improved crop growth, yield attributes and further translocation of nutrients which ultimately affect pod formation associated with increased seed per pod and test weight of seed. The beneficial effect of inorganic fertilizer in growth and yield attributes were also reported by Sarkar et al., (1997), Sankar et al., (1999), Subbarayappa et al., (2009), and Qureshi et al., (2015).

The seed and haulm yields (Table 3) of cowpea were also increased with increase in organic manures application under FYM @ $2.5 \mathrm{t} \mathrm{ha}^{-1}\left(\mathrm{O}_{2}\right)$ wherein significantly higher seed i.e. $919.58 \mathrm{~kg} \mathrm{ha}^{-1}$ and haulm yield i.e. $2247.67 \mathrm{~kg} \mathrm{ha}^{-1}$. The highest seed and haulm yield could be due to the cumulative effect of improvement in yield attributes viz., number of pod per plant, number of seed per pod and 100 seed weight, Harvest index (Table 3) was affected significantly by FYM @ $2.5 \mathrm{t} \mathrm{ha}^{-1}$ $\left(\mathrm{O}_{2}\right)$. 
Table.1 Plant height, number of branches per plant of cowpea as influenced by inorganic fertilizers, organic manures and bio-fertilizer

\begin{tabular}{|c|c|c|c|c|c|c|}
\hline \multirow[t]{2}{*}{ Treatments } & \multicolumn{4}{|c|}{ Plant height (cm) } & \multicolumn{2}{|c|}{$\begin{array}{l}\text { Number of branches per } \\
\text { plant }\end{array}$} \\
\hline & $\begin{array}{l}\text { At } 20 \\
\text { DAS }\end{array}$ & $\begin{array}{l}\text { At } 40 \\
\text { DAS }\end{array}$ & $\begin{array}{l}\text { At } 60 \\
\text { DAS }\end{array}$ & At harvest & At 60 DAS & At harvest \\
\hline \multicolumn{7}{|l|}{ (A) Inorganic Fertilizer } \\
\hline $\mathrm{F}_{1}-\mathbf{5 0} \% \mathrm{RDF}$ & 12.01 & 29.91 & 39.90 & 42.10 & 3.51 & 3.91 \\
\hline $\mathrm{F}_{2}-100 \% \mathrm{RDF}$ & 12.45 & 31.77 & 42.73 & 45.39 & 3.92 & 4.32 \\
\hline S.Em. \pm & 0.27 & 0.56 & 0.89 & 1.08 & 0.088 & 0.087 \\
\hline C.D. at 5\% & NS & 1.70 & 2.71 & 3.26 & 0.268 & 0.266 \\
\hline \multicolumn{7}{|l|}{ (B) Organic manures } \\
\hline $\mathrm{O}_{1}-0 \mathrm{tha}^{-1}$ & 11.90 & 29.81 & 39.73 & 42.04 & 3.58 & 3.98 \\
\hline $\mathrm{O}_{2}-2.5 \mathrm{tha}^{-1}$ & 12.56 & 31.87 & 42.91 & 45.46 & 3.86 & 4.25 \\
\hline S.Em. \pm & 0.27 & 0.56 & 0.89 & 1.08 & 0.088 & 0.087 \\
\hline C.D. at $\mathbf{5 \%}$ & NS & 1.70 & 2.71 & 3.26 & 0.268 & 0.266 \\
\hline \multicolumn{7}{|l|}{ (C) Bio-fertilizers } \\
\hline$B_{1}$ - No inoculation & 11.98 & 30.00 & 39.89 & 42.09 & 3.56 & 3.96 \\
\hline $\begin{array}{l}\mathrm{B}_{2} \text { - Seed inoculation } \\
\text { with Rhizobium and } \\
\text { phosphate solubilizing } \\
\text { bacteria } \\
\end{array}$ & 12.49 & 31.70 & 42.75 & 45.40 & 3.88 & 4.28 \\
\hline S.Em. \pm & 0.27 & 0.56 & 0.89 & 1.08 & 0.088 & 0.087 \\
\hline C.D. at 5\% & NS & 1.70 & 2.71 & 3.26 & 0.268 & 0.266 \\
\hline \multicolumn{7}{|l|}{ Interactions } \\
\hline FXO & NS & NS & NS & NS & NS & NS \\
\hline FX B & NS & NS & NS & NS & NS & NS \\
\hline OX B & NS & NS & NS & NS & NS & NS \\
\hline FXOXB & NS & NS & NS & NS & NS & NS \\
\hline C.V. $\%$ & 7.71 & 6.28 & 7.50 & 8.52 & 8.23 & 7.38 \\
\hline
\end{tabular}


Table.2 Number of nodules per plant, days to $50 \%$ flowering and dry matter accumulation of cowpea as influenced by inorganic fertilizers, organic manures and bio-fertilizer

\begin{tabular}{|c|c|c|c|c|c|}
\hline \multirow[t]{2}{*}{ Treatments } & \multicolumn{2}{|c|}{$\begin{array}{l}\text { Number of nodules } \\
\text { per plant }\end{array}$} & \multirow[t]{2}{*}{$\begin{array}{l}\text { Days to } 50 \% \\
\text { flowering }\end{array}$} & \multicolumn{2}{|c|}{$\begin{array}{l}\text { Dry matter accumulation per } \\
\text { plant }(\mathrm{g})\end{array}$} \\
\hline & $\begin{array}{l}\text { At } 60 \\
\text { DAS }\end{array}$ & At harvest & & At $60 \mathrm{DAS}$ & At harvest \\
\hline \multicolumn{6}{|c|}{ (A) Inorganic Fertilizer } \\
\hline $\mathrm{F}_{1}-\mathbf{5 0} \% \mathrm{RDF}$ & 46.00 & 42.52 & 42.00 & 22.91 & 32.80 \\
\hline $\mathrm{F}_{2}-100 \% \mathrm{RDF}$ & 49.28 & 45.78 & 45.28 & 24.65 & 35.30 \\
\hline S.Em. \pm & 1.06 & 1.06 & 1.06 & 0.47 & 0.80 \\
\hline C.D. at 5\% & 3.22 & 3.22 & 3.22 & 1.45 & 2.44 \\
\hline \multicolumn{6}{|l|}{ (B) Organic manures } \\
\hline $\mathrm{O}_{1}-0$ t ha $^{-1}$ & 45.89 & 42.30 & 41.89 & 22.81 & 32.30 \\
\hline $\mathrm{O}_{2}-2.5 \mathrm{t} \mathrm{ha}^{-1}$ & 49.39 & 46.01 & 45.39 & 24.75 & 35.81 \\
\hline S.Em. \pm & 1.06 & 1.06 & 1.06 & 0.47 & 0.80 \\
\hline C.D. at $\mathbf{5 \%}$ & 3.22 & 3.22 & 3.22 & 1.45 & 2.44 \\
\hline \multicolumn{6}{|l|}{ (C) Bio-fertilizers } \\
\hline $\mathrm{B}_{1}$ - No inoculation & 45.94 & 42.38 & 41.94 & 22.95 & 33.15 \\
\hline $\begin{array}{lr}\mathbf{B}_{2} \quad- & \text { Seed } \\
\text { inoculation } & \text { with } \\
\text { Rhizobium } & \text { and } \\
\text { phosphate } & \\
\text { solubilizing bacteria } \\
\end{array}$ & 49.34 & 45.93 & 45.34 & 24.61 & 34.96 \\
\hline S.Em. \pm & 1.06 & 1.06 & 1.06 & 0.47 & 0.80 \\
\hline C.D. at 5\% & 3.22 & 3.22 & 3.22 & 1.45 & 2.44 \\
\hline \multicolumn{6}{|l|}{ Interactions } \\
\hline FXO & NS & NS & NS & NS & NS \\
\hline FX B & NS & NS & NS & NS & NS \\
\hline $\mathbf{O X ~ B}$ & NS & NS & NS & NS & NS \\
\hline FXOX B & NS & NS & NS & NS & NS \\
\hline C.V. \% & 7.73 & 8.33 & 8.43 & 6.98 & 8.20 \\
\hline
\end{tabular}


Table.3 Yield parameters of cowpea as influenced by various treatments

\begin{tabular}{|c|c|c|c|c|c|c|}
\hline Treatments & $\begin{array}{l}\text { Number } \\
\text { of pod } \\
\text { per plant }\end{array}$ & $\begin{array}{l}\text { Number } \\
\text { of seed } \\
\text { per pod }\end{array}$ & $\begin{array}{l}100 \text { seed } \\
\text { weight }\end{array}$ & $\begin{array}{l}\text { Seed } \\
\text { yield } \\
\text { (kg/ha) }\end{array}$ & $\begin{array}{l}\text { Haulm } \\
\text { yield } \\
\text { (kg/ha) }\end{array}$ & $\begin{array}{l}\text { Harvest } \\
\text { index } \\
(\%)\end{array}$ \\
\hline \multicolumn{7}{|l|}{ (A) Inorganic Fertilizer } \\
\hline $\mathrm{F}_{1}-50 \% \mathrm{RDF}$ & 10.01 & 10.45 & 10.62 & 819.75 & 1998.93 & 29.09 \\
\hline $\mathrm{F}_{2}-100 \% \mathrm{RDF}$ & 10.95 & 11.48 & 11.45 & 917.58 & 2221.33 & 29.22 \\
\hline S.Em. \pm & 0.27 & 0.19 & 0.25 & 29.30 & 72.08 & 0.13 \\
\hline C.D. at 5\% & 0.82 & 0.58 & 0.77 & 88.88 & 218.67 & NS \\
\hline \multicolumn{7}{|l|}{ (B) Organic manures } \\
\hline$O_{1}-0 \mathrm{tha}^{-1}$ & 9.90 & 10.38 & 10.57 & 817.75 & 1972.60 & 29.30 \\
\hline $\mathrm{O}_{2}-2.5 \mathrm{tha}^{-1}$ & 11.06 & 11.56 & 11.51 & 919.58 & 2247.67 & 29.01 \\
\hline S.Em. \pm & 0.27 & 0.19 & 0.25 & 29.30 & 72.08 & 0.13 \\
\hline C.D. at $\mathbf{5 \%}$ & 0.82 & 0.58 & 0.77 & 88.88 & 218.67 & NS \\
\hline \multicolumn{7}{|l|}{ (C) Bio-fertilizers } \\
\hline $\mathbf{B}_{1}-$ No inoculation & 9.98 & 10.51 & 10.61 & 821.75 & 2024.52 & 28.88 \\
\hline $\begin{array}{l}\mathbf{B}_{2}-\text { Seed inoculation with } \\
\text { Rhizobium and phosphate } \\
\text { solubilizing bacteria }\end{array}$ & 10.99 & 11.44 & 11.48 & 915.58 & 2195.75 & 29.43 \\
\hline S.Em. \pm & 0.27 & 0.19 & 0.25 & 29.30 & 72.08 & 0.13 \\
\hline C.D. at $\mathbf{5 \%}$ & 0.82 & 0.58 & 0.77 & 88.88 & 218.67 & 0.41 \\
\hline \multicolumn{7}{|l|}{ Interactions } \\
\hline FXO & NS & NS & NS & NS & NS & NS \\
\hline $\mathbf{F X B}$ & NS & NS & NS & NS & NS & NS \\
\hline OX B & NS & NS & NS & NS & NS & NS \\
\hline FXOX B & NS & NS & NS & NS & NS & NS \\
\hline C.V. \% & 9.00 & 6.09 & 7.99 & 11.68 & 11.83 & 1.61 \\
\hline
\end{tabular}

The improvement seed yield, haulm yield and harvest index were mainly on account of increase in the growth parameters and yield attributes of cowpea due to increasing in rate of organic manures. These results are also in agreement with findings of Sarkar et al., (1997), Sankar et al., (1999), Subbarayappa et al., (2009), and Qureshi et al., (2015).

\section{Effect of bio-fertilizers}

Data presented in Table 1 revealed that difference in plant height at $40 \mathrm{DAS}$, at 60 DAS and at harvest were influenced significantly by the effect of bio-fertilizers.
Significantly the highest plant height at 40 DAS i.e. $31.70 \mathrm{~cm}$, at 60 DAS i.e. $42.75 \mathrm{~cm}$ and at harvest i.e. $45.40 \mathrm{~cm}$ was recorded with seed inoculation with Rhizobium and phosphate solubilizing bacteria $\left(\mathrm{B}_{2}\right)$.

Thus there is an increase in plant height with application of seed inoculation with Rhizobium and Phosphate solubilizing bacteria throughout the crop growth span. The probable reason might be positive effect of nutrient on growth character due to augment of cell division and cell expansion. The study was in close conformity as observed by Meena et al., (2015). 
Significantly higher for number of branches per plant, days to $50 \%$ flowering, number of nodules per plant, dry matter per plant, number of pod per plant, number of seed per pod and 100 seed weight were recorded under the treatment of seed inoculation with Rhizobium and phosphate solubilizing bacteria $\left(\mathrm{B}_{2}\right)$. This might be due to dual inoculation benefited the plants by providing atmospheric $\mathrm{N}$ and rendering the insoluble phosphorus into available form. The enhanced availability of $\mathrm{P}$ favored $\mathrm{N}$ fixation and rate of photosynthesis and consequently led to better growth and yield attributes. The beneficial effect of bio fertilizer in growth and yield attributes were also reported by Beena $e t$ al., (1990), Patel et al., (2013), Das et al., (2014), Khandelwal et al., (2015) and Meena et al., (2015).

The seed and haulm yields (Table 3) of cowpea were also affected significantly under seed inoculation with Rhizobium and phosphate solubilizing bacteria $\left(\mathrm{B}_{2}\right)$. Significantly the higher seed i.e. $915.58 \mathrm{~kg}$ $\mathrm{ha}^{-1}$ and haulm yield i.e. $2195.75 \mathrm{~kg} \mathrm{ha}^{-1}$ were recorded with treatment $B_{2}$. These might be due to significant and progressive effect of dual inoculation of Rhizobium and phosphate solubilizing bacteria on yield attributes resulted in hiher seed \& haulm yield. These results are also in agreement with findings of Dekhane et al., (2011), Patel et al., (2013), Khandelwal et al., (2015), Khan et al., (2015) and Meena et al., (2015).

\section{Interaction Effect}

Interaction effect of inorganic fertilizer, organic fertilizers and bio fertilizers was found non-significant for all the parameters. While numerically higher grain and straw yield obtained with the application of $100 \%$ RDF + FYM @ $2.5 \mathrm{t} \mathrm{ha}^{-1}$ + Seed inoculation with Rhizobium and phosphate solubilizing bacteria. Almost similar findings were also reported by Sammauria et al., (2009) and Gorade et al., (2014).

Based on one year field experimentation, significantly the highest seed and haulm yields were recorded with application of 100 $\%$ RDF, FYM @ $2.5 \mathrm{t} \mathrm{ha}^{-1}$ and seed inoculation with Rhizobium and Phosphate solubilizing bacteria in south Gujarat heavy rainfall Agro-ecological situation III (AESIII).

\section{References}

Abayomi, Y.A., Ajibade, T.V., Sammuel, O.F. and Sa'adudeen, B.F. 2008. Growth and yield response of cowpea (Vigna unguiculata (L.) walp) genotypes to nitrogen fertilizer (NPK) application in the Southeren Guinea Savanna Zone of Nigeria. Asian Journal Plant Science, 7(2): 170-176.

Beena, S., Nair, S.K. and Mathew, J. 1990. Varietal response and host varietal specificity for nodulation by rhizobium in cowpea. Legume Research, 13(3): 136-138.

Das, B., Wagh, A.P., Dod, V.N., Nagre, P.K. and Bawkar, S.O. 2011. Effect of integrated nutrient management on cowpea. Asian Journal Horticulture, 6(2): 402-405.

Dekhane, S.S., Khafi, H.R., Raj, A.D. and Parmar, R.M. 2011. Effect of biofertilizer and fertility levels on yield, protein content and nutrient uptake of cowpea [Vigna unguiculata (L.) Walp.]. Legume Research, 34(1): 51-54.

Gaur, C.A. 1990. Soil Chemical Analysis. Prentice-Hall of India Pvt. Ltd., New Delhi.

Gorade, V.N., Chavanl, S., Jagtap, D.N. and Kolekar, A.B. 2014. Response of green gram (Vigna radiata L.) varieties to integrated nutrient management in 
summer season. Agriculture Science Digest, 34(1): 36-40.

Joshi, J.R., Patel, V.M., Barad, H.L., Macwan, S.M. and Javid, E. 2018. Effect of land configuration and fertilizer management practices on growth, yield and yield attributes and economics of summer cowpea (Vigna unguiculata L.) under south Gujarat condition. International Journal of current Microbiology and Applied Sciences, 7(1): 1148-1155.

Khan, V.M., Manohar, R.S., Verma, H.P. 2015. Effect of vermicompost and biofertilizer on symbiotic efficiency and yield of cowpea in arid zone of Rajasthan. Asian Journal Bioscience, 10(1): 113-115.

Khandelwal R, Choudhary SK, Ghoshlya J, Singh P (2013) Effect of fertilizer and bio-fertilizers on growth, yield and economics of cowpea. Annals Plant Soil Res 15(2): 177-178.

Kumar, D., Arvadiya, L. K.; Kumawat, A. K.; Desai, K. L. and Patel, T. U. (2014). Yield, protein content and uptake of chickpea (Cicer orientinum L.) as influenced by graded level of fertilizer and bio fertilizers. Research Journal of Chemical and Environmental Science, 2(6): 60-64.

Meena, J.S., Verma, H.P. and Pancholi, P. 2015. Effect of fertility levels and biofertilizers on growth and yield of cowpea on sandy loam soil of Rajasthan. Asian Journal Soil Science, 10(1): 55-58.

Patel, R.D., Patel, D.D., Chaudhari, M.P., Surve, V., Patel, K.G. and Tandel, B.B. 2013. Response of different cultivars of green gram (Vigna radiate (L) Wlczek) to integrated nutrient management under south Gujarat condition. An International e Journal, 2(2): 132-142.

Qureshi, F, Bashir, U and Ali, T. 2015. Effect of integrated nutrient management on growth, yield attributes and yield of field pea (Pisum sativum L.) cv. rachna. Legume Research, 38(5): 701-703.

Sammauria, R., Yadav, R.S. and Nagar, K.C. 2009. Performance of clusterbean (Cyamopsis tetragonoloba) as influenced by nitrogen and phosphorus fertilizer and biofertilizers in Western Rajasthan. Indian Journal of Agronomy, 54(3): 319-323.

Sankar, V., Thamburaj, S., Kannan, M., Shanmugam, M. and Veeraragavathatham, D. 1999. Effect of sequential cropping of vegetable cowpea (Vigna unguiculata L Walp) and different levels of FYM and P on growth and yield of cassava (Maninot esculenta Crantz). South Indian Horticulture, 47(16): 89-94.

Sarawd, I.M., Surakod, V.S., Mulla, S.R. and Kabadagi, C.B. 2014. Long term effect of integrated nutrient management on rabi sorghum-chickpea rotation. Bioinfolet, 11 (2A): 367-372.

Sarkar, R.K., Shit, D. and Chakraborty, A. 1997. Effect of levels and sources of phosphorus with and without farmyard manure on pigeon pea under rain fed condition. Indian Journal of Agriculture Science, 42(1): 120-123.

Satodiya, B.N., Patel, H.C. and Soni, N.V. 2015. Effect of planting density and integrated nutrient management on flowering, growth and yield of vegetable cowpea [Vigna unguiculata (L.) Walp]. Asian Journal of Horticulture 10(2): 232-236.

Shankaram, A. 1996. Soil fertility management for reconciling sustainability with productivity. Journal of Indian Society of soil Science, 44(4): 593.

Sharma, S.K., Prajapati, S. and Raghuwanshi, O. 2015. Effect of organic manures and inorganic fertilizers on yield and economics of cowpea production (Vigna 
unguiculata L). Indian Research Journal of Genetics and Biotechnology, 7(1): 152-155.

Shaw, M. 2007. 100 Most Protein Rich Vegetarian Foods. Smarter Fitter Blog. http://smarterfitter.com/blog/2007/10/28 /100-most-protein-rich-vegetarianfoods.

Singh, A., Bhatt, B.P., Sundaram, P.K., Sharma, S.K., Bahrati, R.C., Chandra, N. and Rai, M. 2012. Study of site specific nutrients management of cowpea seed production and their effect on soil nutrient status. Journal of Agriculture Science, 4(10): 191-198.

Subbarayappa, C.T., Santhosh, S.C., Srinivasa, N. and Ramakrishnaparama, V. 2009. Effect of integrated nutrient management on nutrient uptake and yield of cowpea in southern dry zone soils of Karnataka. Mysore Journal of Agricultural Sciences, 43(4): 700-704.

\section{How to cite this article:}

Pargi, K.L., R.L. Leva, H.Y. Vaghasiya and Patel, H.A. 2018. Integrated Nutrient Management in Summer Cowpea (Vigna unguiculata L.) Under South Gujarat Condition. Int.J.Curr.Microbiol.App.Sci. 7(09): 1513-1522. doi: https://doi.org/10.20546/ijcmas.2018.709.181 